УДК [373.3.015.31:17.022.1-044.352]:376-056

DOI: 10.37026/2520-6427-2021-108-4-75-80

\section{Оксана ТРЕТЯК,}

кандидат педагогічних наук, дочент кафедри педагогіки початкової, інклюзивної та вищої освіти

Рівненського державного

гуманітарного університету, м. Рівне, Украӥна

ORCID: 0000-0002-4558-2863

e-mail: ksenijat2017@gmail.com

\section{Оксана МІЩЕНЯ,}

кандидат педагогічних наук,

доцент кафедри педагогіки початкової, інклюзивної та вищої освіти

Рівненського державного

гуманітарного університету,

м. Рівне, Україна

ORCID: 0000-0003-3041-1575

e-mail: oksanamishchenia@gmail.com

\section{Лілія ІСКРА,}

стариий викладач кафедри педагогіки початкової, інклюзивної та вищої освіти

Рівненського державного

гуманітарного університету,

м. Рівне, Україна

ORCID: 0000-0001-5603-7628

e-mail: liliaiskra70@gmail.com

\title{
ОСОБЛИВОСТІ ВИХОВАННЯ ТОЛЕРАНТНОСТІ В УЧНІВ МОЛОДШОГО ШКІЛЬНОГО ВІКУ В ІНКЛЮЗИВНОМУ СЕРЕДОВИЩІ
}

\begin{abstract}
Анотація. Стаття присвячена проблемі виховання толерантності в учнів початкових класів та огляду різноманітних педагогічних підходів до визначення особливостей виховання, щзо сприяють становленню гуманних взаємин між учнями молодшого шкільного віку та їхніми однолітками з особливими освітніми потребами.

Здійснено теоретичний аналіз наукових джерел, щзо висвітлюють певні аспекти виховання толерантності в учнів початкових класів. Окреслено складову виховання толерантності в учнів початкової школи в інклюзивному класі, тобто виховну роботу з ними та їхніми батьками щуодо зміни споживаџького ставлення
\end{abstract}

до життя та оточуючих, зокрема до дітей-однолітків з особливими освітніми потребами.

Результати дослідження засвідчили, щзо для успішної інтеграції дітей з особливими потребами дуже важливим с ставлення до них як педагогів, так і учнів та їхніх батьків. Виховання толерантності до дітей з особливими освітніми потребами вимагає системної роботи з педагогами, учнями та батьками як нормотипових дітей, так і дітей з обмеженими можливостями здоров'я.

Ключові слова: толерантність, виховання толерантності, діти з особливими освітніми потребами, інклюзія, інклюзивна освіта, інклюзивне середовище.

\author{
Oksana TRETYAK, \\ Candidate of Pedagogical Sciences, \\ Associate Professor, \\ Department of Pedagogy, Primary, \\ Inclusive and Higher education, \\ Rivne State Humanitarian University, \\ Rivne, Ukraine \\ ORCID: 0000-0002-4558-2863 \\ e-mail:ksenijat2017@gmail.com
}


Oksana MISCHENYA,

Candidate of Pedagogical Sciences,

Associate Professor,

Department of Pedagogy, Primary,

Inclusive and Higher education,

Rivne State Humanitarian University,

Rivne, Ukraine

ORCID: 0000-0003-3041-1575

e-mail: oksanamishchenia@gmail.com

Liliya ISKRA,

Senior Lecturer,

Department of Pedagogy, Primary,

Inclusive and Higher education,

Rivne State Humanitarian University,

Rivne, Ukraine

ORCID: 0000-0001-5603-7628

e-mail: liliaiskra70@gmail.com

\section{PECULIARITIES OF TOLERANCE EDUCATION OFPRIMARY SCHOOL CHILDREN IN INCLUSIVE ENVIRONMENT}

\begin{abstract}
The article discusses the peculiarities of fostering tolerance among junior school children of inclusive classes to children with special educational need and analyzes various approaches to the education of tolerance among primary school children. It has been devoted to highlight problem of promoting tolerance among primary school children and reviewing various pedagogical approaches to determining pedagogical conditions that contribute to the formation of humane relationships between junior school children and their peers with disabilities and form a tolerant attitude towards them.

The article provides a theoretical analysis of scientific sources that cover various aspects of formation of tolerant culture among primary schoolchildren.

The results of the study showed that for the successful integration of children with special needs, the attitude towards them, both teachers and children and their parents, is very important. Fostering tolerance for children with special needs requires systematic work with educators, children and parents of both normal children and children with limited educational capabilities. The Component of the resin of tolerance is the work with some of the most insulting needs and the fertile for the edification of the need for life and another people.

In the course of the study, the main organizational and pedagogical conditions of fostering a tolerant attitude of primary school students towards children with special educational needs in inclusive classes were determined.

Special pedagogical conditions for creating a tolerant educational environment and fostering tolerance among primary school students in inclusive classes can be considered the formation of such relations between participants in the educational process that ensure the socialization of children through their inclusion in various cultural and social practices in the process of educational and extracurricular activities, while each participant in the educational process has the opportunity to be successful, and his contribution is recognized as important and meaningful to all.
\end{abstract}

Key words: tolerance, education of tolerance, children with special educational needs, inclusion, inclusive education, inclusive environment.

Постановка проблеми. Свроінтеграційний процес в Україні, прагнення держави та суспільства зменшити дискримінацію та забезпечити реалізацію прав людей з інвалідністю, зокрема права дітей з обмеженими можливостями здоров'я на отримання якісної освіти за місцем проживання, зумовили розвиток інклюзивної освіти. Із цією метою здійснюється підготовка педагогічних працівників до такої роботи та введено нову посаду - асистент учителя інклюзивного класу, який має забезпечувати особистісно орієнтоване спрямування освітнього процесу. Однак, на нашу думку, недостатньо забезпечити інклюзію на рівні законодавства, необхідно ретельно підготувати оточення дитини з особливими освітніми потребами. Важливо розуміти, що саме діти, учні формують інклюзивний простір, і для того, щоб дитина 3 порушеннями розвитку психологічно комфортно почувала себе у класі, інші діти також мають почуватися комфортно. У зв'язку з цим важливого значення набуває виховання толерантності як основи спільного навчання дітей, які відрізняються між собою.

Сутністю толерантності є визнання права людини бути інакшою. Це зумовлює розуміння того, що світ і соціальне середовище багатовимірні, а отже, і погляди на цей світ можуть різнитися, їх не можна зводити до однаковості.

Успішною інтеграцією у суспільство є створення педагогічних умов, в яких діти можуть взаємодіяти, спілкуватися й розвиватися відповідно до своїх можливостей, що є метою соціальної реабілітації дітей 3 обмеженими можливостями життєдіяльності. Інклюзивні школи, на думку науковців, є «школами для всіх» (Т. Бут, М. Ейнскоу, В. Засенко, А. Колупаєва, Дж. Леско, М. Малофєєв, Н. Назарова та ін.). 
Зважаючи на зазначене вище, суспільство повинно створити належні умови для задоволення особливих потреб кожної особистості, а не особистість має прилаштовуватися до суспільних, соціальних, економічних відносин - і це є основною ідеєю інклюзивного підходу.

Аналіз наукових досліджень і публікацій. Педагогічні ідеї виховання толерантної особистості окреслюються в багатьох роботах видатних педагогів минулого, де вони приділяли увагу вивченню питань толерантного ставлення до відмінностей між людьми (Г. Ващенко, А. Макаренко, М. Монтессорі, Й. Песталоцці, С. Русова, В. Сухомлинський, Л. Толстой, К. Ушинський та ін.). У сучасній науці реалізація ідей толерантності втілені у педагогіці співробітництва (Ш. Амонашвілі, О. Ільїна, В. Шаталов та ін.), у «педагогіці успіху», «педагогіці діалогу» (І. Волков, С. Ільїн, С. Лисенкова та ін.) та у «педагогіці толерантності» (Т. Арістова, М. Боритко, Г. Палаткіна, Ю. Тодорцева та ін.).

Педагогічний контекст феномена толерантності розглядається в роботах В. Шаліна, І. Беха, В. Калошина, В. Рахматшаєва, Л. Завірюхи не тільки як характеристика індивідуальної свідомості, але й як особлива особистісна якість, що може тією чи іншою мірою сформуватися відповідною педагогічною взаємодією.

У дослідженнях Г. Балла, А. Духновича, В. Кан-Калика, Я. Коменського, А. Макаренка, В. Семиченко, Є. Шиянова знайшли відображення теоретичні засади виховання гуманістичних цінностей та формування професійної свідомості педагога.

У сучасних дослідженнях толерантність визначається як принцип правового, соціально-політичного аспекту (М. Мчедлов), нова філософія (В. Лекторський), категорія міжособистісних відносин (О. Клєпцова, В. Маралов, В. Сітаров, О. Соколова, Г. Солдатова та ін.), толерантна свідомість (О. Асмолов, О. Газман, О. Грива, О. Кондаков, О. Насиновська та ін.), пізнавальна стратегія (А. Коржуєв, Н. Кудзієва, В. Попков, М. Поташник та ін.), особистісна або суспільна характеристика, що передбачає усвідомлення того, що світ і соціальне середовище багатомірні (В. Тішков) та ін.

Проблемам толерантності під час інклюзивного навчання присвячені праці багатьох науковців та дослідників. Так, питання освітньої інтеграції та інклюзії аналізуються у працях Ю. Богінської, Л. Будяка, Л. Вавіної, Н. Ворони, Р. Дименштейн, І. Звєрєвої, Т. Ілляшенко, А. Капської, Н. Мирошніченко, А. Мудрика, Ю. Найди, Н. Софій, С. Хлєбіка та інших.

Питаннями інклюзії цікавилися багато вітчизняних (Н. Ворон, І. Звєрєва, А. Мудрик, Ю. Найда та інші) і закордонних (Т. Міттлер, Т. Лорман, Д. Роза, Д. Харві та інші) учених. У їхніх роботах особлива увага зверталася на проблему здобуття освіти дітьми з особливими освітніми потребами, а також на необхідність формування у педагогів толерантності стосовно цих дітей.

Узагальнення та аналіз науково-методичної літератури, результатів наукових досліджень сучасної педагогічної теорії і практики дають підстави стверджувати про актуальність проблеми виховання толерантності в учнів початкової школи в інклюзивних класах, зокрема формування толерантного ставлення до дітей-однолітків з особливими освітніми потребами. Усе це та виявлені суперечності і зумовили вибір теми нашого дослідження.
Вивчення питань толерантності з розвитком сучасних подій в Україні, пов'язаних із військово-політичним конфліктом, а також проблемою міграції населення тощо, відбувається передусім у соціокультурній та політичній площині. В означеній публікації ми намагаємося розглянути толерантність як основу для створення інклюзивного освітнього середовища.

Метою статті $є$ розкриття особливостей виховної роботи з учнями молодшого шкільного віку щодо формування в них толерантності в умовах інклюзивного середовища на основі теоретичного аналізу досліджень у галузі педагогіки толерантності та інклюзивної освіти.

Виклад основного матеріалу дослідження. Мета інклюзивної освіти - «зробити так, аби жодна дитина з особливими освітніми потребами не відчувала себе іншою, зайвою, небажаною. Тож організація інклюзивних класів і груп у закладах освіти $є$ цінною як для дітей з особливими освітніми потребами та їхніх ровесників, так і для педагогів, батьків, керівників закладів освіти, зрештою - для суспільства загалом» (Інклюзивна освіта в початкових класах Нової української школи: вебсайт, 2021).

Теоретичний аналіз проблеми дав змогу визначити загальні умови, що забезпечують успішну інклюзію у закладі загальної середньої освіти. До таких умов належать: інформаційно-методична, педагогічна, правова, психологічна готовність усіх учасників освітнього процесу до впровадження та підтримки інклюзивної системи навчання.

У педагогіці поняття «толерантність» визначається як якість особистості, що виявляється в готовності приймати людину такою, якою вона є, взаємодіяти на засадах згоди і порозуміння, знаходити виявлення у повазі й визнанні рівності, прагненні до порозуміння 3 іншими, уникненні тиску і домінування (Асмолов, 2000).

Декларація принципів толерантності пропонує тлумачити поняття «толерантність» як повагу, прийняття й розуміння багатого різноманіття культур нашого світу, форм самовираження й способів прояву людської індивідуальності. Отже, толерантність - це гармонія в різноманітті. Її вияв у повазі до прав людини означає право дотримання кожним своїх переконань та визнання такого ж права за іншими, і аж ніяк не терпиме ставлення до соціальної несправедливості чи відмову від своїх переконань. Толерантність передбачає визнання того, що люди за своєю природою відрізняються зовнішнім виглядом, статусом, мовою, поведінкою й цінностями і мають право жити у світі й зберігати свою індивідуальність. Погляди однієї людини не можуть бути нав'язані іншими (Декларація принципів толерантності, 1995).

Зважаючи на зазначене вище, слід відзначити, що «толерантність» не притаманна людині від народження і може ніколи не з'явитися, якщо не буде спеціально виховуватися та формуватися. Так, А. Асмолов щодо цього наголошує, що толерантності необхідно вчитися, досягаючи у власному розвитку мети розуміння й прийняття себе та інших (2000, с. 39-64). Поняття толерантності означає здатність людини співпрацювати, чути, цінувати, розуміти і поважати іншу думку та ставитися до неї з розумінням.

Виховання толерантності у дітей молодшого шкільного віку в умовах закладів освіти передбачає 
інтенсивну взаємодію двох суб'єктів - особистості дитини шкільного віку та безпосередньо вчителя, який покликаний забезпечити належні умови для розвитку дитини. В означеному контексті важливо проаналізувати значення поняття «педагогічні умови»: це умови, від яких залежить результат; вимоги, які висуває одна сторона до іншої; домовленість між сторонами, що закріплена письмово; прийняте правило в будь-якій сфері діяльності. Узагальнюючи, можна зазначити, що умови - це стабільні обставини, які оточують об'єкт та задають характер впливу на нього.

А. Колупаєва у своїх дослідженнях підкреслює, що саме по собі спільне навчання здорових дітей і дітей «особливих» не розв'язує всіх проблем їхньої взаємодії, адже без відповідної педагогічної роботи сфера дитячих стосунків може залишатися деформованою, неповноцінною (Колупаєва, 2009, с. 209).

Позитивні аспекти якісної взаємодії між дітьми та однолітками з обмеженими фізичними можливостями аргументує М. Андрєєва. Перший аспект взаємодії полягає в тому, що діти з особливими освітніми потребами, спілкуючись $з$ однолітками, отримують досвід взаємин із навколишнім середовищем, можливість розширити свій кругозір і соціалізуватися в суспільстві. Важливістю другого аспекту є те, що «здорові діти», спілкуючись із дітьми з особливими освітніми потребами, стають гуманнішими, милосерднішими один до одного, терпимо сприймають людські відмінності. Третій аспект визначає те, що суспільство не завжди толерантно, з розумінням ставиться до людей із фізичними обмеженнями. Основною причиною цього $\epsilon$ недостатність інформації про людей з особливими потребами та відсутність відповідних поведінкових моделей (Андрєєва, с. 38-39).

Т. Сжова обгрунтовує два способи побудови толерантного освітнього простору. Перший полягає «у припиненні негативних реакцій одних дітей щодо інших». Другий спосіб полягає «у створенні необхідних умов для досягнення всіма учнями високого соціального статусу й усвідомлення соціальної значимості кожного 3 них». Крім того, дослідниця визначає основні ознаки створення толерантного середовища: «відкритість для дітей, різних за соціальним статусом, станом здоров'я, зовнішнім виглядом; стійкість до внутрішніх змін та зовнішніх впливів; гуманність, яка передбачає співпрацю та діалог учителя з учнями та їхніми батьками; варіативність, що дає можливість враховувати та задовольняти потреби кожного» (Сжова, 2012, с. 66-71).

Толерантним вважаємо освітнє середовище, в якому педагогічні умови сприяють формуванню толерантної особистості. У педагогічній науці толерантність визначається як певна риса особистості, яка виражається в готовності людини приймати інших такими, якими вони є, взаємодіяти з ними на засадах взаємоповаги, взаєморозуміння, сприйняття інших культур, здатності запобігати конфліктам або розв'язувати їх ненасильницькими методами (О. Асмолов, Н. Атаманчук, Л. Бернадська, І. Бех, Б. Гершунський, Т. Сжова, О. Сакалюк, О. Сараєва, Л. Хоружа, М. Черемський та ін.).

Протилежним до толерантності явищем є нетерпимість - неприйняття інших. Інтолерантним середовищем можна вважати таке, де існує неприйняття іншого тільки за те, що він виглядає, думає, діє інакше
(Т. Сжова, 2012). Так, Л. Шипіцина виокремлює основні прояви інтолерантності в інтегрованому дитячому середовищі: 1) дитина прагне до однолітків, але однолітки iii не сприймають; 2) дитина прагне до однолітків, іiї не відштовхують, але спілкування є формальним; 3) дитина відособлюється від однолітків, вони також не виявляють до неї інтересу; 4) дитина уникає контактів з однолітками, а вони уникають контактів 3 нею $(2009$, с. 142).

У дослідженнях Г. Люльки, В. Ляпунової, А. Молчанової та Л. Чередник висвітлюється проблема формування у майбутніх педагогів професійної здатності до міжособистісної толерантності, що визначає критерії готовності педагогів до роботи з виховання толерантності у дітей молодшого шкільного віку і виражається толерантним ставленням до дітей та установкою на особистісно орієнтовану модель взаємодії з ними.

Дії педагога мають бути спрямовані на полегшення страждань жертви і повернення ініціаторів кепкувань на шлях примирення, адже діти, кепкуючи над іншими, в майбутньому стають дорослими, котрі схвалюють інтолерантність і несправедливість у своїх громадах. Головне в роботі вчителя - спрямованість змісту діяльності учнів, регулювання міжособистісних відносин, вміння сформувати у дітей правильне ставлення до інклюзивного учня.

Ознаки толерантного вчителя окреслює у своїх дослідженнях нідерландська дослідниця Б. Ріердон, зокрема: толерантний учитель усвідомлює, що його сприймають як зразок для наслідування; він опановує та використовує відповідні навички для розвитку діалогу й мирного розв'язання конфліктів; заохочує творчі підходи до вирішення проблем; забезпечує умови для спільної конструктивної активності учасників освітнього процесу; не заохочує агресивну поведінку та суперництво; сприяє залученню учнів і батьків до прийняття рішень і розробки програм спільної діяльності; вчить мислити критично й уміє цінувати позиції інших. Для ознайомлення дослідниця пропонує книгу «Толерантність - дорога до миру», що містить поради для вчителів початкової ланки, середніх і старших класів щодо того, як боротися з нетолерантністю в школі, розвивати атмосферу дружби в колективі, допомагати жертвам нетолерантності. Цей посібник є частиною програми ООН, що висвітлює проблеми глобальної дегуманізації суспільства, в якому ростуть діти, що стають жорстокими і нетерпимими один до одного. Авторка книги намагається допомогти виховати толерантну людину i переконана - починати потрібно з педагога. Передусім у школі має панувати толерантне середовище $\mathrm{i}$, за словами дослідниці, цього легко досягти, демонструючи школярам різноманітність цього світу. Також у праці перераховуються ознаки того, що в колективі панує інтолерантність, зокрема це насмішки, дискримінація тощо (Риэрдон, 1996, с. 54-55).

Основним засобом реалізації виховання толерантності в учнів початкових класів є інтерактивне педагогічне спілкування. М. Бандурка у педагогічному спілкуванні виділяє комунікативні, інтерактивні та перцептивні процеси в системі «вчитель - учні». Саме інтерактивна складова комунікативної компетентності вчителя виявляється у способах і прийомах виховного впливу на учнів, у тактиці та стратегії організації педагогічної взаємодії. Інтерактивне спілкування пов'язане з організацією спільної діяльності людей, їхньої 
взаємодії. Для того, щоб організувати спільну діяльність під час виховного процесу важливо не просто налагодити обмін інформацією, а й виробити спільну стратегію, техніку взаємодії. Саме інтерактивне спілкування передбачає досягнення взаєморозуміння, докладання зусиль із метою подальшої організації спільної діяльності (Бандурка та ін., 2003).

Важливо зазначити, що всі педагогічні засоби освітнього процесу тією чи іншою мірою впливають на виховання толерантності в дітей. Формування толерантного ставлення учнів до дітей-однолітків 3 особливими освітніми потребами базується на знанні педагогом індивідуальних особливостей дітей, досвіду взаємин між дітьми та їх проявами у поведіниі. Після вивчення й аналізу ситуації педагоги здійснюють пошук ефективних форм виховання в дітей толерантності, визначають конкретний зміст цієї роботи.

Наразі відзначається тенденція до зниження коефіцієнту емоційної мудрості від покоління до покоління. Однак емоційна мудрість учителя має важливе значення та полягає в умінні розуміти та ефективно керувати не тільки власними емоціями, але й емоціями оточення як у професійному, так і особистому житті. У зв'язку 3 цим дуже важливо, щоб педагоги засвоїли навички осягнення емоцій, адекватно і своєчасно застосовуючи їх у вихованні. Осягнення емоцій передбачає наявність таких чинників, як самопізнання, турбота про інших, особиста ефективність. Відсутність в учнів належного емоційного стану зазвичай зумовлює появу в них комунікативних труднощів, які зникають, коли вчитель поліпшує настрій дітей.

Із метою формування толерантних міжособистісних стосунків у дитячому колективі інклюзивного класу найбільш сприятливою є колективна творча діяльність дітей із соціально та особистісно значущим змістом. У зв'язку з цим можуть бути використані всі види навчальної й позаурочної роботи, зміст яких націлений на формування моральних взаємин між людьми. Ефективність спільної діяльності дітей як засобу формування толерантності підвищується, якщо вони усвідомлюють її мету й знаходять у ній особистісний зміст. За цієї умови здійснюється спільне планування, організація й підведення підсумків діяльності, а також реалізується педагогічно доцільний розподіл ролей і функцій між дітьми й педагогом; створюються ситуації вільного вибору дітьми видів і способів діяльності. У зв'язку з цим кожен учасник може реалізувати себе, домогтися успіху та водночас виявити турботу про інших, зробити реальний внесок у спільну справу. Виховний потенціал спільної діяльності зростає, якщо вона має творчий характер (Ю. Азаров, Р. Вайнола, І. Зязюн, Л. Лузіна, Н. Ничкало, С. Сисоєва та ін.).

Колективна творча діяльність сприяє вихованню толерантності, якщо діти у процесі іiі реалізації набувають досвіду гуманної партнерської взаємодії з педагогом та між собою. Для того, щоб забезпечити психологічну захищеність дитини, успішність ії взаємин з іншими, педагог має створювати спеціальні ситуації, що дозволяють дітям здійснювати взаємодопомогу, приймати самостійні рішення, висловлювати власні судження та водночас із повагою ставитися до думки інших. Діти, які надають допомогу дітям з особливими освітніми потребами, мають змогу навчатися та виховуватися за принципом «рівний - рівному», що допомагає здоровим дітям підвищити самооцінку, відчути свою важливість для суспільства, навчитися товаришувати.

Особливої уваги в інклюзивній освіті вимагає групове навчання (Л. Даниленко, І. Демченко, А. Колупаєва, Н. Ткачова). Постійна робота в команді заради спільної мети допомагає дітям реалізовуватися та водночас ігнорувати відмінності між собою. Учитель повинен створити середовище, в якому вони відчуватимуть підтримку, власну цінність, а також важливість у процесі навчання. Ролі мають бути значущими та періодично змінюватися, адже кожен учень повинен спробувати себе у якості лідера групи.

Толерантність у дитини набагато легше сформувати, якщо однодумцями педагогів в означеному питанні є іiі батьки. Негативне ставлення до появи в класі дитини з особливими потребами, за свідченням педагогів-практиків, висловлюють до 60 \% батьків здорових дітей. За цієї умови важливо здійснювати цілеспрямовану роботу з батьками здорових учнів, роз'яснювати їм важливість виховання в дітей толерантності й культури міжособистісного спілкування.

Такі дослідники, як Т. Сжова, А. Колупаєва, Ю. Найда, О. Онопрієнко, Н. Софій наголошують на важливості співпраці та діалозі вчителя з учнями та їхніми батьками, що базуються на гуманності у період становлення нової, поки що нетрадиційної як для школи, так і для суспільства загалом, соціальної ситуації. Така ситуація не завжди спонукає до співробітництва, співчуття і співпереживання та вимагає цілеспрямованої педагогічної роботи з вибудовування толерантних взаємин між усіма учасниками освітнього процесу.

Виховувати толерантність у родині - це прищеплювати повагу, прийняття і правильне розуміння багатого різноманіття культур нашого світу, різних форм самовираження і способів прояву людської індивідуальності. У зв'язку з цим із батьками здорових учнів необхідно проводити цілеспрямовану роботу, роз'яснювати їм важливість виховання в дітей толерантності й культури міжособистісного спілкування. В означеному контексті педагог повинен бути прикладом толерантного ставлення до інших, демонструвати позитивний зразок гуманної взаємодії з родиною. На нашу думку, тільки такий комплексний підхід забезпечить ефективність виховання толерантності у сучасних учнів початкової школи в інклюзивному середовищі.

Дослідження особливостей виховання толерантності в учнів початкової школи в інклюзивних колективах дало змогу виокремити найефективніші педагогічні умови, що сприяють становленню гуманних взаємин між учнями початкових класів та їхніми однолітками 3 особливими освітніми потребами. Усе це сприяє створенню у навчальному закладі толерантного освітнього простору, цілеспрямованому та активному використанню змісту освітніх галузей та форм організації освітнього процесу з метою формування в учнів початкових класів еталонів толерантного ставлення до оточуючих, підготовці вчителів та батьків до виховання толерантності молодших школярів в умовах інтерактивного педагогічного спілкування та залученню учнів і їхніх батьків до програм спільної діяльності, у ході якої учні вчаться мислити критично і цінувати позиції інших.

Висновки. Отже, необхідною умовою впровадження та розвитку інклюзивної освіти в Україні $€$ 
виховання толерантності у дітей молодшого шкільного віку. Під поняттям «толерантність» стосовно дітей 3 особливими освітніми потребами розуміємо здатність бачити в людині з обмеженими освітніми потребами саме людину, а не іiї обмежені можливості чи інвалідність, людину іншої зовнішності, поведінки, носія інших цінностей, логіки мислення, усвідомлення іiі права бути іншою, відмінною.

Результати дослідження дозволили виокремити основні особливості виховання толерантності в учнів молодшого шкільного віку в інклюзивному класі. Це свідчить про необхідність здійснення інформаційно-роз'яснювальної роботи, психолого-педагогічної та медико-соціальної просвіти усього населення, а також проведення системної роботи з батьками здорових дітей та педагогічним персоналом закладів загальної середньої освіти, спрямованої на зміну в усіх учасників освітнього процесу негативних соціальних установок, стереотипів щодо дітей із психофізичними порушеннями, формування толерантного ставлення до таких дітей і гармонізацію стосунків в учнівському колективі.

Особливими педагогічними умовами створення толерантного освітнього середовища та виховання толерантності в учнів початкової школи в інклюзивних класах можна вважати формування таких взаємин між учасниками освітнього процесу, що забезпечують соціалізацію дітей через включення їх у різноманітні культурні й соціальні практики в процесі навчальної й позаурочної діяльності. За цієї умови кожен учасник освітнього процесу має можливість бути успішним, а його внесок визнається важливим і значимим для всіх.

Перспективи подальших досліджень убачаємо в методичному забезпеченні організації цілеспрямованої виховної роботи в закладах інклюзивної освіти на основі толерантного підходу та дослідженні проблеми формування толерантних взаємин учасників освітнього процесу в закладах освіти, де створені інклюзивні класи.

\section{СПИСОК ВИКОРИСТАНОЇ ЛІТЕРАТУРИ}

Асмолов, А. Г. (2000). Толерантность: от утопии - к реальности. На пути к толерантному сознанию. Москва: Смысл. 255 с.

Інклюзивна освіта в початкових класах НУШ. (2021). URL: https://www.pedrada.com.ua/article/2593nklyuzivna-osvta-v-pochatkovy-shkol-nush/ (дата звернення: 31.05.2021) Париж.

Декларація принципів толерантності. (1995).

Колупаєва, А. А. (2009). Інклюзивна освіта: реалії та перспективи: монографія. Київ: Самміт-Книга. 272 с.

Андреєва, М. О. (2013). Формування толерантності учнів початкової школи в інклюзивному навчальному закладі. Проблеми сучасної педагогічної освіти. Педагогіка і психологія: збірник наукових праць Кримського гуманітарного університету. Ялта: РВВ КГУ. Вип. 39 (2). С. 36-41.

Єжова, Т. Є. (2012). Організаційно-педагогічні умови створення толерантного освітнього середовища інклюзивної школи. Актуальні проблеми навчання та виховання людей з особливими потребами: збірник наукових праць. Київ: Національна бібліотека України ім. В. І. Вернадського. № 9 (11). С. 66-71.

Шипицына, Л. М. (2009). Ребенок с нарушенным слухом в семье и обществе. Санкт-Петербург: Речь. $201 \mathrm{c}$.

Риэрдон, Б. Э. (1996). Толерантность - дорога к миру. Москва: Бонфи. 304 с.

Бандурка, М., Тюріна, В., Федоренко, О. (2003). Основи психології і педагогіки: підручник. Харків. 298 c.

Кузмінський, А. I. (2006). Педагогіка у запитаннях і відповідях: навчальний посібник для вузів. Київ: Знання. 311 с.

\section{REFERENCES}

Asmolov, A. H. (2000). Tolerantnost: ot utopyy - k realnosty [Tolerance: from utopia to reality]. Na puty $k$ tolerantnomu soznanyiu. Moskva: Smysl. 255 s. [in Russian].

Inkliuzyvna osvita $\mathrm{v}$ pochatkovykh klasakh NUSh [Inclusive education in primary shool NUSH]. (2021). URL: https://www.pedrada.com.ua/article/2593-nklyuzivna-osvta-v-pochatkovy-shkol-nush/ (data zvernennia: 31.05.2021). [in Ukrainian].

Deklaratsiia pryntsypiv tolerantnosti [Declaration of Principles of Tolerance]. (1995). Paryzh. [in Ukrainian].

Kolupaieva, A. A. (2009). Inkliuzyvna osvita: realii ta perspektyvy [Inclusive education: realities and prospects]: monohrafiia. Kyiv: Sammit-Knyha. 272 s. [in Ukrainian].

Andreieva, M. O. (2013). Formuvannia tolerantnosti uchniv pochatkovoi shkoly $\mathrm{v}$ inkliuzyvnomu navchalnomu zakladi [Formation of tolerance of primary school students in an inclusive educational institution]. Problemy suchasnoi pedahohichnoi osvity. Pedahohika i psykholohiia: zbirnyk naukovykh prats Krymskoho humanitarnoho universytetu. Yalta: RVV KHU. Vyp. 39 (2). S. 36-41. in Ukrainian].

Yezhova, T. Ye. (2012). Orhanizatsiino-pedahohichni umovy stvorennia tolerantnoho osvitnoho seredovyshcha inkliuzyvnoi shkoly [Organizational and pedagogical conditions for creating a tolerant educational environment of an inclusive school]. Aktualni problemy navchannia ta vykhovannia liudei z osoblyvymy potrebamy: zbirnyk naukovykh prats. Kyiv: Natsionalna biblioteka Ukrainy im. V. I. Vernadskoho. № 9 (11). S. 66-71. [in Ukrainian].

Shypytsyna, L. M. (2009). Rebenok s narushennym slukhom v seme y obshchestve [A child with a disturbed hearing in the family and society]. Sankt-Peterburh: Rech. 201 s. [in Russian].

Ryerdon, B. Э. (1996). Tolerantnost - doroha k myru [Tolerance is the road to peace]. Moskva: Bonfy. 304 s. [in Russian].

Bandurka, M., Tiurina, V., Fedorenko, O. (2003). Osnovy psykholohii i pedahohiky [Basics of psychology and pedagogy]: pidruchnyk. Kharkiv. 298 s. [in Ukrainian].

Kuzminskyi, A. I. (2006). Pedahohika u zapytanniakh i vidpovidiakh [Pedagogy in Q\&A : a study guide for universities]: navchalnyi posibnyk dlia vuziv. Kyiv: Znannia. 311 s. [in Ukrainian].

Дата надходження до редакиіï: 09.11.2021 p. 